\title{
THE EFFECTS OF DIVERSITY MANAGEMENT AND INCLUSION ON ORGANISATIONAL OUTCOMES: A CASE OF MULTINATIONAL CORPORATION
}

\author{
Folakemi OHUNAKIN ${ }^{1}$, Anthonia ADENIJI ${ }^{2}$, Olaleke Oluseye OGUNNAIKE ${ }^{3}$, \\ Friday IGBADUME ${ }^{4}$, Dayo Idowu AKINTAYO ${ }^{5}$
}

\author{
1, 2, 3, 4 Department of Business Management, College of Business and Social Sciences, Covenant University, Nigeria \\ ${ }^{5}$ Faculty of Management Sciences, Osun State University \\ E-mails: ${ }^{1}$ folakemi.ohunakin@stu.cu.edu.ng; ${ }^{2}$ anthonia.adeniji@covenantuniversity.edu.ng; \\ ${ }^{3}$ olaleke.ogunnaike@covenantuniversity.edu.ng; ${ }^{4}$ igbadume.friday@stu.cu.edu.ng; ${ }^{5}$ dayo.akintayo@uniosun.edu.ng
}

Received 27 November 2018; accepted 16 December 2018

\begin{abstract}
This article provides an empirical study on effects of diversity management and inclusion on organisational outcomes. The importance of diversity management and inclusion on organisation is of immense benefit especially in a Multinational Corporations, where diversity and inclusion are parts of their core values. However, in our context, which had been identified as the most diverse country in Africa, there is need to establish how the management and inclusion of these diverse workforce would benefit organisational activities, coupled with the fact that, there is dearth of research on these constructs in extant literature. This study investigated the effects of diversity management and inclusion on organisational outcomes (job satisfaction and job performance) among Shell Corporation employees. Pen and paper questionnaire of 384 copies were administered to the Lagos Branch employees of Shell Corporation. Cross-sectional research design was adopted. Confirmatory Factor Analysis (CFA), convergent and divergent validity, correlational analysis, and structural equation model were used for the analysis. The findings showed positive effect of diversity management and inclusion on employees' job satisfaction and employees' job performance. It implies that diversity management and inclusion have the potentials of assisting organisation in creating a climate in which employee will like to work harder with readiness to continue to work with the organisation.
\end{abstract}

Keywords: diversity management, inclusion, job satisfaction, job performance, Shell Corporation, Nigeria.

JEL Classification: M54.

\section{Introduction}

Management and inclusion of diverse workforce had become a major concern and salient problem in organizations across all sectors (Choi, 2017). Diversity management and inclusion are required for organisational survival in order to be able to meet up with the dictate of the spate of globalization around the world. Diversity involves recognising, respecting, accepting and tolerating individual uniqueness and differences. It is a construct that depicts the differences in individuals' gender, race, ethnicity, age, religious beliefs, socioeconomic status, physical abilities, sexual orientation and other ideologies. Inclusion on the other hand, has been described as the involvement of employees in the organisational systems and processes (Downey et al. 2015). Adequate exploration of these differences in a secured and conducive environment would promote harmonious workplace, especially in an organisation that employs diverse people such as multinational corporations. In developed nations such as Europe and United States, workplace diversity management and inclusion have received adequate recognition. However, in emerging economies such as Nigeria, the state of diversity management and inclusion are yet to be established especially in multinational corporations such as Shell petroleum where there is multicultural workforce.

Copyright (C) 2019 The Authors. Published by VGTU Press.

This is an Open Access article distributed under the terms of the Creative Commons Attribution License (http://creativecommons.org/licenses/by/4.0/), which permits unrestricted use, distribution, and reproduction in any medium, provided the original author and source are credited.. 
In Society for Human Resource Management (2009) study carried out on 47 countries regarding global diversity and inclusion, Nigeria was ranked $45^{\text {th }}$ overall. Despite the fact that, Nigeria has been identified as one of the five most diversed population in their study, and the most diversed country in the continent of Africa. The study further identified Nigeria as a nation with diverse population and various religion background, with high level of tribal, ethnic and religion conflicts, as well as unending crisis among various socioeconomic classes and so on. Furthermore, Hwang and Hopkins (2015) advocated for replication of their study on diversity management on organisational outcomes in other human service organisations in order to be able to generalise their outcomes. However, Shell Nigeria is a corporation for human services that provides work environment that accommodates everybody irrespective of their gender, tribe, religion, ethnic, physical abilities and social class among others. In addition, in Nigeria context, few research has been done on diversity management and inclusion as they relate with the employee as one of the major stakeholders.

For instance, Nzeadibe et al. (2015) study centred on cultural diversity and community perception in Nigeria. Ogbo and Kifordu (2015) researched on management of diversity as a strategy for development sustainability in developing nation. Adeleye et al. (2012) worked on diversity management in Nigeria: “The Chevron Way”. Ogbo et al. (2014) conducted qualitative research on the influence of workforce diversity on organizational performance in selected Nigeria's firms. Moreover, these studies were qualitative research, by implication there is scarcity of empirical study in Nigeria context especially in multinational corporations where diversity and inclusion are parts of their core values.

In the same vein, Singal (2014) argued that, diversity is a social imperative and a desirable aspect of organisation's activities, the scholar further stated that, the influence of diversity management and inclusion on workplace behaviour have received little attention, moreover, the findings of the existing studies on these constructs are inconsistent. However, within the multinational corporations, to the best of our knowledge, the direct influence of diversity management and inclusion on employee job satisfaction and job performance had not been established, this study intends to fill this gap. This scenario is worth of investigation in a

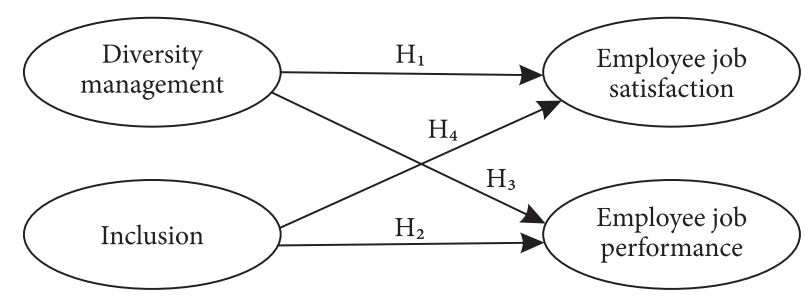

Figure 1. The schematic model of the study country with high level of discrimination, and in a corporation that preaches against discrimination. This study therefore seeks to establish the impact of diversity management and inclusion on employees' organizational outcomes in Lagos branch of Shell Corporation. The hypotheses are as indicated in Figure 1 and the specific objectives are to:

Ascertain the interaction between diversity management and employees' job satisfaction.

Identify how inclusion impacts employee job performance.

Establish how diversity management influences employees' job performance.

Determine how inclusion relates with employee job satisfaction.

\section{Review of literature}

\subsection{Diversity management}

The practices of diversity management have evolved over time. Before 1970s, the major approach to diversity management were liberal and radical approaches. According to Kirton and Greene (2010), liberal approach was under the philosophy of sameness, while radical approach was under the philosophy of positive discrimination. Diversity management has been defined as the utilization of human resources management practices for maintaining variations in human capital and ensure that such variations do not have negative influence towards the achievement of the organizational goals and objectives (Olsen and Martins 2012). Kirton and Greene (2010) described diversity management as valuing employees' differences and effectiveness in the usage of such differences. The scholars further argued that diversity management has gained greater recognition in recent time, and it is a phenomenon that advocated for Equal Employment Opportunity (EEO) and Affirmative Action (AA) laws among others. Affirmative action programs in the United States were stemmed out of the civil right movement towards the eradication of cultural/ racial discrimination, and so on, while affirmative action programs in Australia were centered on combatting the issue of gender discrimination. According to Konrad et al. (2006) Affirmative Action programs comprises organizational goals for adequate representation of historically excluded groups, and mapping out strategies for achieving the goals, while Manoharan et al. (2014) argued that Equal Employment Opportunity is majorly being driven by legislation. Kossek et al. (2006) accentuated that, diversity management involves commitment to EEO, although, diversity management scope is much broader. In the opinion of Jayne and Dipboye (2004) there are varieties of programs in diversity management, the vital components include initiative for recruitment, promotion and retention of diverse group of workforces. 


\subsection{Inclusion}

According to Ortlieb and Sieben (2014) inclusion is a new concept among researchers and still at its infancy stage in the organisational literature, this is one of the major reasons why much study has not been done on it, they therefore advocated for more empirical work on this concept as it relates with organisational practices. Also, in Shore et al. (2011) it was argued that, despite the fact that inclusion has started gaining popularity, it is still a new concept with no consensus among researchers as regards its definition. Therefore, scholars had given definition in their various ways. For instance, HanappiEgger (2012) defined inclusion as a means of valuing and enabling employees' full participation in the entire organisational activities. Ponce-Pura (2014) defined inclusion as the individual employees' sense of belongingness as it relates to their experiences and perceptions being recognized for their qualities and individuality within the organisational context. In the opinion of April and Blass (2010) inclusion of employees in organisation's processes and procedures has to do with equal opportunity among workforce in the workplace. Roberson (2006) described inclusion as the removal of hindrances to the employee full participation and contribution to organisational activities.

\subsection{Job satisfaction}

Job satisfaction of employees is a crucial indicator of positive performance outcomes in any organisation (Ohunakin 2018). This requires the leadership of every organisation to influence followers towards the achievement of common goals. Son and Ok (2018) and Omonijo et al. (2015) argued that increase in employees' job satisfaction is one of the major responsibilities of the organisation, which would consequently have positive influence on the organisational productivity. According to Zhu (2013), the formal definition of job satisfaction stemmed out of the studies carried out by Fisher and Hanna in 1931, where job satisfaction was described as a product of non-regulatory mood tendency. In Dilig-Ruiz et al. (2018) job satisfaction was defined as outcome of the overall nature of the job and person's expectations, and perceptions of various components of the work environment. In Ohunakin et al. (2018), it was stated that job satisfaction is a positive attitude or pleasant emotional state derived from valuing someone's effort in terms of achievements. Castellacci and Viñas-Bardolet (2019) opined that the level of individual employee's job satisfaction varies depending on perception of such individual about the antecedents, such as career prospect and value for income.

\subsection{Job performance}

Employee performance can be described as the extent of accomplishment an individual attain on a given task over a particular period of time. It can also be regarded as measuring actual output of an individual employee with the intended output. In the earlier work of Campbell et al. (1990) employee performance has been defined as the level of individual employee performance which differentiate such from the organisational performance. Muindi and K'Obonyo (2015) described employee performance as a multi-dimensional construct which can be defined from the perspective of outcomes or behaviour. The outcome aspects are those results or consequences of individual employee's behaviour that can be influenced by various environmental factors, while behavioural aspects are the contributions of individual employee's to a given assignment that have impact on the goals and objectives of the organisation (Campbell et al. 1993).

\subsection{Workplace diversity, inclusion, employees' job satisfaction and employees' job performance}

According to Odhiambo (2014) study on educational sector in Kenya, a positive significant relationship exists between workforce diversity management and employees' job performance. Kyalo (2015) also found positive impact of diversity management on employees' job performance. In harmony with Odhiambo et al. (2013) also reported a significant effect of diversity management on employees' job performance. Conversely, Ely (2004) and Kochan et al. (2003) study revealed no positive interaction between diversity management and organizational performance in their different research. Similarly, Leonard et al. (2004) discovered negative influence of diversity management on employees' performance. Darwin and Palanisamy (2015) study revealed no significant effect between workforce diversity and employees' job performance in Singapore.

McNeely (1989) reported positive effect of diversity management on job satisfaction among the professionals in Hispanic American human services. Pitts (2009) also found a positive significant influence of diversity management on employees' job satisfaction. Similarly, Lee and Lee (2012) recorded positive interaction between workforce diversity management and employees' job satisfaction. In contrast, Campbell (2011) established no significant positive relationship between diversity management and employees' job satisfaction. Stazyk et al. (2012) argued that effectiveness in diversity management has great potential to influence positive organizational outcomes such as job satisfaction.

Telcom (2015) reported that, employees' perception of inclusion has strong positive impact on their job satisfaction among the Norwegian workforce. In the earlier studies, researchers had found that employees' perception of inclusion and acceptance by the co-workers and the organization would positively influence their job satisfaction (DeFrank and Ivancevich 1998, Findler et al. 2007). Similarly, Acquavita et al. (2009) stated that, inclusion 
positively influence employees' job satisfaction among social workers. In the opinion of Thomas and Ely (1996) workforce inclusion among other things would result in greater employees' performance, and consequently enhance organisational productivity. Singal and Gerde (2015) and Choi (2017) stated that, there had been inconsistencies in the earlier studies on diversity management, and employees' job performance and job satisfaction. Moreover, there are dearth of studies on inclusion and organizational outcomes especially in a multinational corporation in our context. Given these arguments, we test the following hypotheses:

Hypothesis $1\left(\mathrm{H}_{1}\right)$ : Diversity management will have positive impact on employees' job satisfaction.

Hypothesis $2\left(\mathrm{H}_{2}\right)$ : Inclusion will influence employees' job performance positively.

Hypothesis $3\left(\mathrm{H}_{3}\right)$ : Diversity management will positively affect employees' job performance.

Hypothesis $4\left(\mathrm{H}_{4}\right)$ : Inclusion will have positive interaction with employees' job satisfaction.

\section{Methods, sample, data collection and measuring tool}

The major purpose of this study is to examine how diversity management and inclusion relate with employees' job performance and employees' job satisfaction in Lagos State branch of Shell Corporation. Cross-sectional research design was adopted in this study. 5-point likert scale questionnaire, ranging from (1) strongly disagree to (5) strongly agree was used as the measuring instrument for data gathering as it relates with the interaction between diversity management, inclusion, employee job satisfaction and employee job performance among 384 Shell Corporation employees in Lagos, Nigeria. This measuring instrument was divided into five parts (A-E). The first part (part A) comprises the demographic questions of the respondents. The second part (part B) addressed the questions on diversity management. The eight dimensions of diversity management of Larkey (1996) Workplace Diversity Questionnaire (WDQ) was considered for this study. This includes inclusion, ideation, understanding, treatement, power, cohesiveness, detail, values. After the confirmatory factor analysis (CFA) was conducted, two of these were excluded because their factor loading was lower than the threshold of 70\% as recommended by Fornell and Larcker (1981). However six (6) dimensions of diversity management for culturally diversed workgroups in an organizational context of Larkey (1996) was adapted for this study. The third part (part C) centered on questions on inclusion as it relates with work group involvement (WGI), influence in decision making (IDM) and access to information and resources (AIR) developed by Cho and Mor Barak (2008). Fourth part (part D) focused on the questions on employee job satisfaction adapted from Minnesota Satisfaction Questionnaire (MSQ) as used in Martins and Proenca (2012). The fifth part (part E) addressed questions on employee performance role based performance scale (RBPS) adapted from Welbourne et al. (1997). These adapted measuring instrument were subjected to modifications, three scholars and experts in the field of human resources evaluated the questionnaire for clarity and content, for it to be able to fit into the context of this study and to eliminate ambiguity. Analysis was done by Stata 14 .

\section{Data analysis}

This study utilized various form of analyses. The demographic profile of the 384 employees of Lagos branch of Shell corporation was analysed using frequency and percentage. Confirmatory factor analysis (CFA) was used to assess the measurement model in order to validate the research constructs. Convergent and divergent validity was done to test whether the findings support the distinction of the parameters included in the study model. Structural Equation model (path analysis) was adopted for testing the four hypothesis.

Table 1. Descriptive statistics of demographic variables

\begin{tabular}{|l|c|c|c|c|}
\hline $\begin{array}{c}\text { Demographic } \\
\text { Characteristics }\end{array}$ & Mean & $\begin{array}{c}\text { Standard } \\
\text { Deviation }\end{array}$ & $\begin{array}{c}\text { Mini- } \\
\text { mum }\end{array}$ & $\begin{array}{c}\text { Maxi- } \\
\text { mum }\end{array}$ \\
\hline Gender & 1.40 & 0.49 & 1 & 2 \\
\hline Age & 2.31 & 0.95 & 1 & 4 \\
\hline $\begin{array}{l}\text { Educational } \\
\text { Level }\end{array}$ & 3.07 & 0.26 & 3 & 4 \\
\hline Marital Status & 1.52 & 0.52 & 1 & 3 \\
\hline Year of Service & 2.47 & 1.07 & 1 & 4 \\
\hline
\end{tabular}

The descriptive statistics for the respondents' demographic profile is as shown in Table 1, indicating the mean, standard deviation, minimum value and maximum value. Through face-to-face means, 436 copies of questionnaire were distributed to employees of Shell Corporation in Lagos. The Shell corporation employees were contacted for participation, and it was communicated to them that they have the right to agree or not. The usable copies of questionnaire were 385 , which represented $88 \%$ response rate. Majority of the respondents were female (54.7\%) with the total number of 210 , while 174 were men (45.3\%). Educational qualifications of the respondents revealed that $9(2.3 \%), 6(1.7 \%)$, 267 (69.5\%), 36 (9.4\%), and 15 (3.9\%) were SSCE (Senior School Certificate Examination), Vocational diploma, B.Sc/BA (first University degree), M.Sc/MBA/MA (second University degree) and $\mathrm{PhD}$ respectively. Age bracket 30-39 has the highest number of the respondents which accounted for 159 representing $41.4 \%$, followed by age bracket $20-29$ with 102 respondents representing $26.6 \%$, age bracket $40-49$ has 87 respondents which is $22.6 \%$ of the total respondents, 


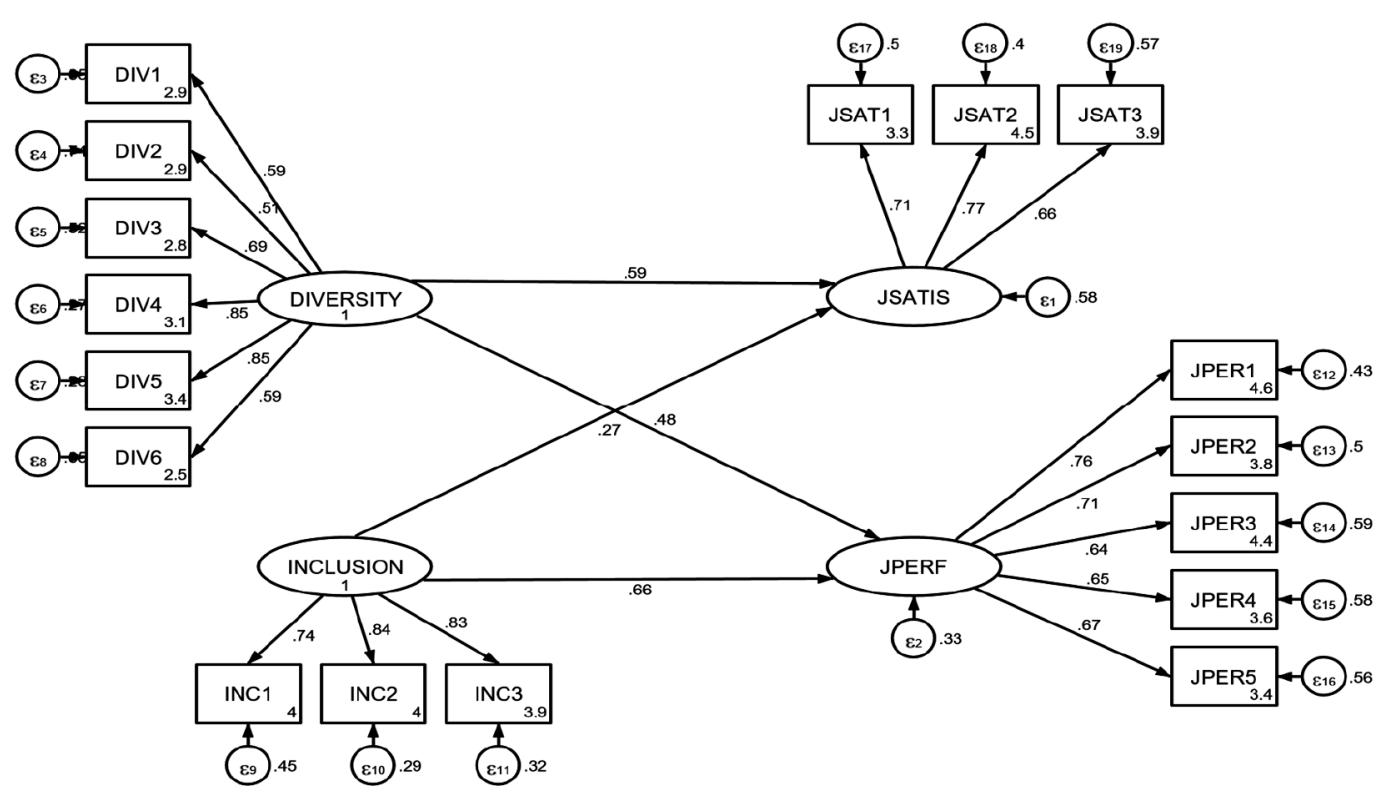

Figure 2. Model with standardized coefficients for diversity management, inclusion, job satisfaction and job performance

while the remaining 36 respondents were in age 50 and above, representing $9.4 \%$ of the total respondents. Igbo ethnic group has the highest number of 162 (42.2\%), followed by Yoruba ethnic group 126 (32.8\%), Hausa ethnic group has 60 respondents representing $15.6 \%$, while the remaining $36(9.4 \%)$ were non-Nigerians. Christian religion has the highest number of respondents of 213 (55.5\%), Islamic religion has a total number of 144 (37.5\%) respondents, while the remaining 27 (7\%) belong to the other religion. Regarding marital status of the respondents, 288 (75.0\%), 72 (18.8\%) were married, were single, 18 (4.7\%) were divorced, while the remaining $6(1.6 \%)$ were others.

\subsection{Reliability analyses}

This study adopted Cronbach Alpha to assess the reliability of the parameters. According to Lee et al. (2017), a satisfactory and acceptable reliability coefficient must be equal to or greater than 0.70 . In this study, the reliability coefficient for diversity management was 0.84 , for inclusion was 0.83 , for job satisfaction was 0.76 and for job performance was 0.83 as shown in Table 2. However, each of these constructs has satisfactory reliability coefficient. As indicated in Table 2, the 17 items observed were significant $(t>1.96$, $\mathrm{p}<0.05)$. The average variance extracted ranged between 0.47 and 0.65 , and the findings support the distinction of the variables in the model. In line with the opinion of Bagozzi and Yi (1989), these AVE were greater than 0.50, excluding job performance (0.47) which was lower than 0.50 . However, the composite reliability (CR) of job performance was 0.82 , which was greater than the value of 0.60 as recommended in Bagozzi and Yi (1989) study. It implies that, its convergent validity was still valid and acceptable. As indicated in Table 3, correlation analysis was conducted to ascertain if there is any significant correlation between the measurement model constructs.

\subsection{Test of hypothesis and discussion}

Hypothesis 1 investigates the effect of diversity management on employees' job satisfaction. According to Table 4 and Figure 2, the standardized direct (path) effect of diversity management on employees' job satisfaction is 0.595 (approximately 60\%), its standard error is $0.059, \mathrm{Z}$ statistics is 9.92. This is highly significant at $\mathrm{p}<0.001$. Hence, hypothesis 1 was accepted. This implies that diversity management have significant positive effect on employees' job satisfaction among the workforce in Shell corporation. This result corroborated the finding from Choi (2017) where significant positive effect of diversity management on employees' job satisfaction was established. Similarly, Ordu (2016) had earlier found positive relationship between diversity management and employees' job satisfaction among the teachers who are working in the public high school in Turkey. Likewise Buckingham (2010), Demirel et al. (2012), Asif et al. (2011), Pitts (2009) and, Chen and Choi (2008) had found positive interaction between diversity and employees' job satisfaction in their different studies.

Hypothesis 2 concerns the influence of inclusion on employees' job performance. As shown in Table 4 and Figure 2 , inclusion has positive influence on employees' job performance to the extent of standardized direct path of 0.665 
Table 2. Confirmatory factor analysis

\begin{tabular}{|c|c|c|c|c|c|c|}
\hline Variable & $\begin{array}{c}\text { Standardized } \\
\text { Factor } \\
\text { Loading }\end{array}$ & $\begin{array}{c}\text { Standard } \\
\text { Error }\end{array}$ & $\mathrm{t}$-value & $\begin{array}{l}\text { Average } \\
\text { Variance } \\
\text { Extracted }\end{array}$ & $\begin{array}{l}\text { Composite } \\
\text { Reliability }\end{array}$ & $\begin{array}{c}\text { Cronbach } \\
\text { Alpha }\end{array}$ \\
\hline Diversity Management & & & & 0.50 & 0.843 & 0.84 \\
\hline DIV1 & 0.5884 & 0.0426 & 13.79 & & & \\
\hline DIV2 & 0.5083 & 0.0474 & 10.71 & & & \\
\hline DIV3 & 0.6903 & 0.0248 & 19.79 & & & \\
\hline DIV4 & 0.8520 & 0.0238 & 35.79 & & & \\
\hline DIV5 & 0.8511 & 0.0239 & 35.65 & & & \\
\hline DIV6 & 0.5924 & 0.0423 & 14.01 & & & \\
\hline Inclusion & & & & 0.65 & 0.846 & 0.83 \\
\hline INC1 & 0.7390 & 0.0329 & 22.47 & & & \\
\hline INC2 & 0.8432 & 0.0247 & 34.07 & & & \\
\hline INC3 & 0.8274 & 0.0255 & 32.48 & & & \\
\hline Job Satisfaction & & & & 0.51 & 0.757 & 0.76 \\
\hline JSATI1 & 0.71 & 0.0375 & 18.85 & & & \\
\hline JSATI2 & 0.77 & 0.0353 & 21.87 & & & \\
\hline JSATI3 & 0.66 & 0.0399 & 16.49 & & & \\
\hline Job Performance & & & & 0.47 & 0.817 & 0.83 \\
\hline JPER1 & 0.76 & 0.0293 & 25.82 & & & \\
\hline JPER2 & 0.71 & 0.0322 & 21.90 & & & \\
\hline JPER3 & 0.64 & 0.0356 & 17.91 & & & \\
\hline JPER4 & 0.65 & 0.0349 & 18.56 & & & \\
\hline JPER5 & 0.67 & 0.0335 & 19.86 & & & \\
\hline
\end{tabular}

Table 3. Descriptive statistics and correlations for constructs

\begin{tabular}{|l|l|c|c|c|c|c|c|}
\hline & \multicolumn{1}{|c|}{ Variables } & Mean & SD & 1 & 2 & 3 & 4 \\
\hline 1 & Diversity Management & 3.20 & 0.70 & $(.74)$ & & & \\
\hline 2 & Inclusion & 4.02 & 0.57 & $41^{\star *}$ & $(.71)$ & & \\
\hline 3 & Job Satisfaction & 3.63 & 0.62 & $24^{\star *}$ & $35^{\star *}$ & $(.70)$ & \\
\hline 4 & Job Performance & 3.70 & 0.61 & $19^{* *}$ & $28^{\star *}$ & $20^{\star *}$ & $(.76)$ \\
\hline
\end{tabular}

Note: Root mean square of Average Variance Extracted are along the diagonal $n=384,{ }^{* *} \mathrm{p}<0.01$

(approximately 67\%), standard error of 0.054 , Z statistics of 12.40, which is significant at $\mathrm{p}<0.001$. This however, informed the acceptance of hypothesis 2 . This finding indicated that inclusion has positive effect on employees' job performance among the Shell Corporation employees. This outcome is in line with the finding of Cho and Mor Barak (2008) in their study on understanding diversity and inclusion on employees' commitment and performance among Korean workforce. These scholars further stated that, when employees perceived that they are adequately involved in the corporate mainstream of the organisation, they feel included, their inclusion perception will increase, which will propel their job performance. Significant number of studies had likened the concept of inclusion with the concept of participation (Cho and Mor Barak 2008). However, earlier studies such as Denison (1990) Stamper and Masterson (2002) found positive interaction between participation and employees' job performance.

Hypothesis 3 examines the relationship between diversity management and employees' job performance. As indicated in Table 4 and Figure 2, there is a positive interaction between diversity management and employees' job performance, the standardized path coefficient between diversity management and employees' job performance revealed 0.482 (approximately 48\%), its standards error was 0.058 , and the $Z$ statistics was 8.33 with $\mathrm{p}<0.001$ level of significance. This prompted the acceptance of hypothesis 3. This outcome shows that diversity management 
Table 4. Standardized path coefficient for testing of hypotheses

\begin{tabular}{|l|c|c|c|l|}
\hline \multicolumn{1}{|c|}{ Hypothesized Path } & $(\beta)$ & S.E & Z Value & Hypothesis Testing \\
\hline H1: Diversity Management $\rightarrow$ Job Satisfaction & 0.595 & 0.059 & 9.92 & Supported \\
\hline H2: Inclusion $\rightarrow$ Job Performance & 0.665 & 0.054 & 12.40 & Supported \\
\hline H3: Diversity Management $\rightarrow$ Job Performance & 0.482 & 0.058 & 8.33 & Supported \\
\hline H4: Inclusion $\rightarrow$ Job Satisfaction & 0.266 & 0.073 & 3.65 & Supported \\
\hline
\end{tabular}

Note: $\beta=$ Beta Value, S.E $=$ Standard Error

impact positively on employees' job performance of Shell Corporation. This finding is consistent with finding from Ugwuzor (2018), where positive correlation was established between diversity and employees' productivity. Ordu (2016) had earlier found positive relationship between diversity management and employees' job performance among the teachers who are working in the public educational sector in Turkey. Similary, Pitts (2009) also found positive effect of diversity management on job performance among the employees in the US federal agencies. In addition, Qasim (2017) established positive effect of diversity management on employees' performance in educational sector in Afghanistan.

Hypothesis 4 investigates the impact of inclusion on employees job satisfaction. As indicated in Table 4 and Figure 2, there is positive significant impact of inclusion on employees' job satisfaction, to the extent of 0.266 (approximately $27 \%$ ), the standard error is 0.073 , Z-value is 3.65 and $\mathrm{p}<0.001$ significance level. Then, hypothesis 4 was not rejected. It implies that inclusion increases employees' job satisfaction among the Shell Corporation workforce. This finding corroborates the result from Hwang and Hopkins (2015) study on diversity taxonomies and inclusion on organisational behavior among public child welfare workers. It is also consistent with earlier research findings, including Acquavita et al. (2009), Mor Barak et al. (2006) and Mor Barak and Levin (2002) among others.

\section{Conclusions and practical implication of findings}

In line with the reviewed literature, four hypotheses were formulated for this study and all of them were supported, Base on these empirical findings, adequate diversity management and inclusion can increase employees' job satisfaction and job performance Our findings make several significant contributions to the literature. It has contributed to extant literature on diversity management, inclusion, job satisfaction and job performance. In our context, this study provides empirical evidence of the effect of Larkey (1996) Workforce Diversity Questionnaire (WDQ) on employees' job satisfaction and employees' job performance. Also, the interactions between inclusion of Cho and Mor Barak (2008) and employees' job satisfaction and job performance were empirically established. There is no doubt, diversity management has certain challenges, nonetheless, organisations can benefit immensely if it is properly managed. Extant literature has suggested that, organisations should consider diversity management and inclusion as two sides of a coin that cannot be separated, in order to obtain positive employees' workplace attitude and behaviour (Ikeije and Lekan-Akomolafe 2015). This will conseqently assist the management in boosting their job satisfaction and increase their job performance. Hence, achieving their set goals and objectives. It is therefore concluded that, the better the management of the diverse workforce, and adequate inclusion of the employees in the various organisational activities, the more favourable their attitude and workplace behaviour.

This study results have some practical implications for leaders, managers and policy makers that are interested in getting the best out of the employees' which will boost the economy of their organisations. Actions for enhancement of on-going training for managers and supervisors on management of diversified workforce and inclusion. Consistency in the evaluation of communication lines for adequate dissemination of information regarding organisational policies and procedures, which is an integral part of inclusiveness. Management/ managers should ensure that the practices within the organisation foster development of workforce, consultation and readiness for feedback that will promote employees' job performance and boost their job satisfaction. In addition, one of the major piority of management is to guide against employee turnover. This implies that, the management should focus more on fostering positive work attitude and behaviour related to employees' job satisfaction and job performance because they are fundamentals for reducing rate of turnover in workplace.

\section{Limitations and area of further research}

This study has several limitations. First, this study sample was drawn from one of the branches of (although the largest branch) a multinational corporation, in order to be able to generalize the findings of this study, it is suggested that it should be replicated in other part of this nation, as well as other multinational corporations. Second, this study is suggested to be replicated in other African countries, with lesser level of diversity, because Nigeria has been identified as the most diversed country in the continent of Africa, with 
numerous ethnic, cultural, tribal, religious groups among others (Society for Human Resource Management 2009). Third the usage of cross-sectional design in the collection of data has limited the causal inference of the findings. Third, the subjective nature of the measuring instruments could be regarded as a limitation. Though, the employees' subjective perceptions supplied adequate information about their organisation realities. It is suggested that future studies should consider some objective measures, such as, capturing data through interview, open-ended questions, observation, focused-group and so on.

\section{Acknowledgements}

Researchers wish to acknowledge Covenant University for sponsoring this article, and also for creating enabling environment for this research.

\section{References}

Adeleye I, Aja-Nwachukwu F, Fawehinmi F (2012) Managing diversity in Nigeria: “The Chevron Way". Human Resource Management Journal: Journal of the CIPMN 4 (1): 1-13.

Acquavita SP, Pittman J, Gibbons M, Castellanos-Brown K (2009) Personal and organizational diversity factors' impact on social workers' job satisfaction: Results from a national Internetbased survey. Administration in Social Work 33: 151-166. https://doi.org/10.1080/03643100902768824

April K, Blass E (2010) Measuring diversity practice and developing inclusion. Dimensions 1 (1): 59-66.

Asif M, Choudhry AI, Akhter SA, IIyas MA, Lee G (2011) Diversity management's effect on job satisfaction and workgroup performance of government sector employees. Interdisciplinary Journal of Comtemporary Research in Business 3 (2): 533-539.

Bagozzi R, Yi Y (1989) On the use of structural equation models in experimental designs. Journal of Marketing Research 26: 271-284. https://doi.org/10.1177/002224378902600302

Buckingham C (2010) A case study exploring the impact of managing workplace diversity on diversity awareness and employee job satisfaction. PhD Thesis, Capela University. Published by ProQuest LLC. UMI Number: 3387665.

Campbell DG (2011) Diversity and job satisfaction: reconciling conflicting theories and findings. International Journal of Applied Management and Technology 10 (1): 1-15.

Campbell JP, McCloy RA, Oppler SH, Sager CE (1993) A theory of performance. In: Schmitt N and Borman WC (Eds) Personnel selection in organizations. Jossey-Bass, San Francisco, 3570.

Campbell JP, McHenry JJ, Wise LL (1990) Modeling job performance in a population of jobs. Personnel Psychology 43 (2): 313-333. https://doi.org/10.1111/j.1744-6570.1990.tb01561.x

Castellacci F, Viñas-Bardolet C (2019) Internet use and job satisfaction. Computer in Human Behaviour 90: 141152. https:// doi.org/10.1016/j.chb.2018.09.001

Choi S (2017) Workforce diversity and job satisfaction of the majority and the minority: analyzing the asymmetrical effects of relational demography on whites and racial/ ethnic minorities. Review of Public Personnel Administration 37 (1): 84-107. https://doi.org/10.1177/0734371X15623617

Chen P, Choi Y (2008) Generational differences in work values: a study of hospitality management. International Journal of Contemporary Hospitality Management 20 (6): 595-615. https://doi.org/10.1108/09596110810892182

Cho S, Barak MEM (2008) Understanding of diversity and inclusion in a perceived homogeneous culture: a study of organizational commitment and job performance among Korean employees. Administration in Social Work 32 (4): 100-126. https://doi.org/10.1080/03643100802293865

Darwin JR, Palanisamy CS (2015) the effects of work force diversity on employee performance in Singapore organisations. International Journal of Business Administration 6 (2): 17-29.

DeFrank RS, Ivancevich JM (1998) Stress on the job: An executive update. The Academy of Management Executive 12 (3): 55-66.

Demirel Y, Seckin Z, Yucel I (2012) Comparative study on the relationship between the management of diversity and job satisfaction. Interdisciplinary Journal Research in Business 2 (7): 12-25.

Denison DR (1990) Corporate culture and organizational effectiveness. New York: John Wiley \& Sons.

Dilig-Ruiz A, MacDonald I, Varin MD, Vandyk A, Graham ID, Squires JE (2018) Job satisfaction among critical care nurses: A systematic review. International Journal of Nursing Studies 88: 123-134. https://doi.org/10.1016/j.ijnurstu.2018.08.014

Downey SN, Werff L, Thomas KM, Plaut VC (2015) The role of diversity practices and inclusion in promoting trust and employee engagement. Applied Social Psychology, 1-10. https:// doi.org/10.1111/jasp.12273

Ely RJ (2004) A field study of group diversity, participation in diversity education programs, and performance. Journal of Organisational Behaviour 25 (6): 755-780. https://doi. org/10.1002/job.268

Findler L, Wind LH, Barak MEM (2007) The challenge of workforce management in a global society: modeling the relationship between diversity, inclusion, organizational culture, and employee well-being, job satisfaction and organizational commitment. Administration in Social Work 31 (3): 63-94. https://doi.org/10.1300/J147v31n03_05

Fornell C, Larcker DF (1981) Evaluating structural equations with unobservable variables and measurement error. Journal of Marketing Research (18): 39-50. https://doi. org/10.1177/002224378101800104

Hanappi-Egger E (2012) Theoretical perspectives on diversity in organisation. In: Danowitz MA, Hanappi-Egger, Mensi-Klarbach H (Eds) Diversity in organisations: Palgrave Macmillan.

Hwang J, Hopkins KM (2015) A structural equation model of the effects of diversity characterisitcs and inclusion on organizational outcomes in the child welfare workforce. Children and Youth Service Review 50: 44-52. https://doi.org/10.1016/j. childyouth.2015.01.012

Ikeije U, Lekan-Akomolafe C (2015) Employees diversity and inclusion: a paradigm shift in organizational management. European Journal of Business and Management 7 (14): 34-39.

Jayne MEA, Dipboye RL (2004) Leveraging diversity to improve business performance: research findings and 
recommendations for organisations. Human Resource Management 43 (4): 409-424. https://doi.org/10.1002/hrm.20033

Kochan T, Bezrukova K, Ely R, Jackson S, Joshi A, Jehn K, Leonard J, Levine D, Thomas D (2003) The effects of diversity on business performance: report of diversity research network. Human Resource Management 42 (1): 3-21. https://doi. org/10.1002/hrm.10061

Konrad A, Prasad P, Pringle JK (2006) Handbook of workplace diversity. California: Sage Publications Ltd.

Kirton G, Greene AM (2010) Theorizing policy approaches to equality and diversity. In: Kirton G, Greene AM (Eds) The dynamics of managing diversity. Butterworth-Heinemann Oxford, 117-140.

Kossek EE, Lobel SA, Brown J (2006) Human resource strategies to manage workforce diversity: examining the business case. In: Konrad AM, Prasad P, Pringle JK (Eds) Handbook of workplace diversity. Sage, Thousand Oaks, CA, 53-74. https:// doi.org/10.4135/9781848608092.n3

Kyalo JMK (2015) Effect of diversity in workplace on employee performance in the banking industry in Kenya. Strategic Journal of Business \& Change Management 2 (53): 145-181.

Larkey LK (1996) The development and validation of the workforce diversity questionnaire: An instrument to assess interactions in diverse workgroups. Management Communication Quarterly 9 (3): 296-377. https://doi.org/10.1177/0 893318996009003002

Lee C, Lee JW (2012) Analysis of the relationships between the hospitality workforce and job-satisfaction factors according to age, gender, native language and racial-ethnicity. Journal of Tourism and Hospitality 1 (104): 1-8. https://doi. org/10.4172/2167-0269.1000104

Lee CH, Hung CC, Chien CS, Zhuang WL, Hsu CYY (2017) Regulatory foci and expatriate adjustment. Personnel Review 46 (3): 512-525. https://doi.org/10.1108/PR-03-2015-0077

Leonard JS, Levine DI, Joshi A (2004) Do birds of a feather shop together? The effects on performance of employees' similarity with one another and with customers. Journal of Organizational Behaviour 25 (6): 731-754. https://doi.org/10.1002/job.267

Manoharan A, Gross MJ, Sardeshmukh SR (2014) Identityconscious vs identity-blind: Hotel managers' use of formal and informal diversity management practices. International Journal of Hospitality Management 51: 1-9. https://doi. org/10.1016/j.ijhm.2014.04.007

Martins D, Proenca T (2012) Satisfaction towards human resources practices and repatriates' retention: An empirical examination in the Portuguese companies context. European Institute for Advanced Studies in Management 4 (7): 221-235.

McNeely RL (1989) Gender, job satisfaction, earnings, and other characteristics of human service workers during and after midlife. Administration in Social Work 13 (2): 99-116. https:// doi.org/10.1300/J147v13n02_07

Mor Barak ME, Levin A (2002) Outside of the corporate mainstream and excluded from the work community: A study of diversity, job satisfaction and well-being. Community, Work and Family 5: 133-157. https://doi.org/10.1080/ 13668800220146346

Mor Barak ME, Levin A, Nissly JA, Lane CJ (2006) Why do they leave? Modeling child welfare workers' turnover intentions.
Children and Youth Services Review 28: 548-577. https://doi. org/10.1016/j.childyouth.2005.06.003

Muindi F, K’Obonyo P (2015) Quality of work life, personality, job satisfaction, competence, and job performance: a critical review of literature. European Scientific Journal 11 (26): 223-240.

Nzeadibe TC, Ajaero CK, Okonkwo EE, Okpoko PU, Akukwe TI, Njoku-Tony RF (2015) Integrating community perceptions and cultural diversity in social impact assessment in Nigeria. Environmental Impact Assessment Review 55: 74-83. https:// doi.org/10.1016/j.eiar.2015.07.005

Odhiambo OW, Kyalo JMK, Ngao E, Mwangi C (2013) Effects of managing gender of employees in enhancing organizational performance. A case study of Kenya ports authority. European Journal of Business and Management 5 (21): 50-62.

Odhiambo OW (2014) Workforce diversity and its effects on employee performance: a case of Mbita sub county HomaBay County in Kenya. Doctoral dissertation, Moi University.

Ogbo A, Kifordu AA (2015) Diversity Management Research (DMR) As a strategy for sustainable development in the third world: experiences and future plans of intellectuals. Procedia - Social and Behavioural Sciences 195: 1303-1310. https://doi.org/10.1016/j.sbspro.2015.06.299

Ogbo AI, Kifordu AA, Ukpere WI (2014) The effect of workforce diversity on organizational performance of selected firms in Nigeria. Mediterranean Journal of Social Sciences 5 (10): 231236. https://doi.org/10.5901/mjss.2014.v5n10p231

Ohunakin F, Adeniji AA, Oludayo OA, Osibanjo AO (2018) Survey dataset on leadership styles and job satisfaction: the perspective of employees of hospitality providers. Data in brief 19: 2178-2188. https://doi.org/10.1016/j.dib.2018.06.033

Ohunakin F (2018) Talent retention strategies and employees' behavioural outcomes in Nigeria's hospitality industry. Unpublished Doctoral Thesis. Department of Business Studies, School of Business, College of Development Studies, Covenant University, Ota, Ogun State, Nigeria.

Olsen JE, Martins LL (2012) Understanding organizational diversity management programs: a theoretical framework and directions for future research. Journal of Organisational Behaviour 33 (8): 1168-1187. https://doi.org/10.1002/job.1792

Omonijo DO, Oludayo OA, Eche GO, Uche OC, Ohunakin F (2015) Intentional turnover of the administrative staff in a private faith-based higher institution, Southwest Nigeria. Mediterranean Journal of Social Sciences 6 (2): 424-434. https://doi.org/10.5901/mjss.2015.v6n2s1p424

Ordu A (2016) The effects of diversity management on job satisfaction and individual performance of teachers. Academic Journals 11 (3): 105-112.

Ortlieb R, Sieben B (2014) The making of inclusion as structuration: empirical evidence of a multinational company, equality, diversity and inclusion. An International Journal 33 (3): 235-248.

Pitts D (2009) Diversity management, job satisfaction and performace: Evidenced from US federal agencies. Public Administration Review 69 (2): 328-338. https://doi.org/10.1111/j.15406210.2008.01977.x

Ponce-Pura MPA (2014) Diversity and inclusion in a multinational corporation: Senior managers' perceptions across three Asian regions. Unpublished Thesis. 
Qasim M (2017) Effect of workforce diversity on employee's job performance: the empirical assessment of education sector, Jalalabad, Afghanistan. International Journal of Economics \& Management Sciences 6 (5): 1-4. https://doi.org/10.4172/21626359.1000452

Roberson Q (2006) Disentangling the meaning of diversity and inclusion in organisations. Group and Organisation Management 31 (2): 212-236. https://doi.org/10.1177/ 1059601104273064

Shore LM, Randel AE, Chung BG, Dean MA, Ehrhart KH Singh G (2011) Inclusion and diversity in work groups: A review and model for future research. Journal of Management 37 (4): 1262-1289. https://doi.org/10.1177/0149206310385943

Society for Human Resource Management (2009) Global diversity and inclusion: perceptions, practices and attitudes: a study for the society for human resource management, Conducted by the Economist Intelligence Unit. 1800 Duke Street, Alexandria, VA 22314 USA.

Singal M (2014) The business case for diversity management in the hospitality industry. International Journal of Hospitality Management 40: 10-19. https://doi.org/10.1016/ j.ijhm.2014.02.009

Singal M, Gerde VW (2015) Is diversity management related to financial performance in family firms? Journal of Family Business Review 28 (3): 143-259. https://doi.org/10.1177/ 0894486514566012

Son J, Ok C (2018) Extraversion as a moderator in the curvilinear relationship between newcomers' organizational tenure and job satisfaction. Journal of Vocational Behaviour 110, Part A: 72-88. https://doi.org/10.1016/j.jvb.2018.11.002

Stamper CL, Masterson SS (2002) Insider or outsider? How employee perceptions of insider status affect their work behavior. Journal of Organizational Behavior 23: 875-894. https://doi. org/10.1002/job.175

Stazyk EC, Davis RS, Liang J (2012) Examining the links between workforce diversity, organizational goal clarity, and job satisfaction. Annual Meeting and Exhibition of the American Political Science Association, New Orleans, LA.

Telcom YT (2015) Job satisfaction in a diverse workforce: to examine the relationship between employees with minority background and job satisfaction. Unpublished Master Thesis. University of Stavanger Faculty of Social Sciences, The Norwegian School of Hotel \& Tourism.

Thomas DA, Ely RJ (1996) Making differences matter: a new paradigm for managing diversity. Harvard Business Review 74: 79-90.

Ugwuzor M (2018) Gender management and behavioural outcomes of women at work. International Journal of Management Studies 2 (5): 82-91. https://doi.org/10.18843/ijms/v5i2(5)/11

Welbourne TM, Johnson DE, Erez A (1997) The role-based performance scale: validity analysis of a theory-based measure. Working Paper 9: 7-05.

Zhu Y (2013) A review of job satisfaction. Asian Social Science 9 (1): 31-45. 